\title{
APLIKASI MANAJEMEN DATA PEMINJAMAN DAN PENGEMBALIAN MOBIL DI PUSFATJA LAPAN
}

\author{
Priyo Utomo ${ }^{1}$, Lukman $^{2}$, Nia Damayanti ${ }^{3}$ \\ ${ }^{1,2,3}$ Teknik Informatika, Fakultas Teknik dan Ilmu Komputer, Universitas Indraprasta PGRI Jakarta \\ Jalan Raya Tengah No 80, Kelurahan Gedong, Pasar Rebo, Jakarta Timur \\ 1.priyou8@gmail.com, ${ }^{21 k m n a j a 50 @ g m a i l . c o m, ~}{ }^{3}$ nia88damayanti@gmail.com
}

\begin{abstract}
ABSTRAK
Permasalahan yang terdapat pada Pusfatja LAPAN adalah terjadinya kehilangan berkas pada saat pelaporan bulanan kepada pimpinan diakibatkan human error serta kendala yang timbul adalah pada saat proses pendataan dan sering terjadi kesalahan pencatatan, dan pelaporan. Tujuan merancang suatu sistem informasi peminjaman dan pengembalian mobil ini dengan tujuan untuk memudahkan admin dalam memproses pengolahan data yang ada saat ini. Perangkat aplikasi yang telah dibuat dengan bahasa pemrograman Java NetBeans 8.0.2 dan penyimpanan data pada database MySQL dapat memberikan kelancaran dalam proses menginput dan penyimpanan data-data serta laporan-laporan yang diberikan kepada Pimpinan perusahaan. Dengan menggunakan metode pengembangan sistem yaitu Waterfall dalam penelitian ini adalah dengan tahapan-tahapan seperti rekayasa sistem, analisis, desain, coding, testing, dan maintenance. Hasil dari penelitian ini menciptakan suatu sistem informasi peminjaman dan peminjaman mobil dapat memudahkan pihak perusahaan dalam proses pendataan data karyawan, data peminjaman mobil karyawan serta proses pendataan data pengembalian mobil yang lebih baik dan akurat.
\end{abstract}

Kata Kunci: Sistem Informasi, Peminjaman, Pengembalian, Java

\begin{abstract}
The problems found in Pusfatja LAPAN are the occurrence of file loss during monthly reporting to the leadership due to human error and the obstacles that arise during the data collection process and frequent recording and reporting errors. The purpose of designing an information system for borrowing and returning this car is to make it easier for admins to process existing data processing. Application devices that have been created with the Java NetBeans 8.0.2 programming language and data storage in the MySQL database can provide smoothness in the process of inputting and storing data and reports given to company leaders. By using the system development method, namely Waterfall, in this research, the stages are systems engineering, analysis, design, coding, testing, and maintenance. The results of this study create a car loan and loan information system that can facilitate the company in the process of collecting employee data, employee car loan data and the data collection process for returning cars that are better and more accurate.
\end{abstract}

Key Word: Information System, Borrow, Return, Java

\section{PENDAHULUAN}

Pada saat ini sistem aplikasi sangat berpengaruh disegala bidang kehidupan baik dibidang politik, pendidikan, maupun ekonomi, khususnya dibidang peminjaman kendaraan operasional perusahaan (Khasbi, Nugraha, \& Muzid, 2016). Tetapi dalam kenyataan masih banyak ditemukan perusahaan yang masih menerapkan metode manual dan sistem manajemen dan administrasinya (Pratama \& Sariana, 2019). Sehingga kesiapan untuk melayani kebutuhan para karyawan belum maksimal dan menyulitkan dalam pengontrolan data dan pembuatan laporan kepada pimpinan. Untuk menghasilkan mutu informasi yang baik, serta secara akurat dalam memperbaiki kesalahan-kesalahan yang sedang terjadi dalam pekerjaan dengan sistem yang manual, maka perusahaan membutuhkan suatu sistem komputer yang dapat membantu kinerja serta mengefesiensikan berbagai sumber daya seperti waktu dan semua sumber daya (Ramadhani, Saputra, Syahfitri, \& Herlawati, 2019). Proses manajemen dan pencatatan data tidak bisa dipisahkan dengan suatu perkembangan teknologi informasi, dikarenakan setiap keputusan manajemen selalu membutuhkan dukungan dari 
teknologi informasi begitu pula dengan manajemen data (Puspaningrum \& Sudarmilah, 2020).

PUSFATJA LAPAN dibentuk berdasarkan peraturan Kepala Lembaga Penerbangan dan Antariksa Nasional No. 2 Tahun 2011 tanggal 4 maret 2011 tentang organisasi dan tata laksana Lembaga Penerbangan dan Antariksa Nasional yang mengacu kepada keputusan Presiden Republik Indonesia Nomor 103 tahun 2001 tentang kedudukan, tugas, fungsi, kewenangan, susunan organisasi dan tata kerja Lembaga Pemerintah Non Departemen. PUSFATJA LAPAN yang beralamat di Jl. Kalisari No.8, RT.11/RW.1, Pekayon, Pasar Rebo, Jakarta Timur 13710. Permasalahan saat ini proses peminjaman dan pengembalian mobil perusahaan dalam pencatatannya masih manual dengan media kertas dan sering terjadi human error, pelaporan kepada pimpinan pun terkadang sering mengalami keterlambatan. Dengan kondisi seperti ini dibutuhkan sistem informasi dalam mengatasi permasalahan yang ada didalam perusahaan (Wahyudi, 2019).

Dengan permasalahan tersebut, perlu ada nya suatu sistem yang terkomputerisasi dalam penyelesaiannya. Sistem adalah sekelompok unsur yang erat hubungannya satu dengan yang lain, yang berfungsi bersama-sama untuk mencapai tujuan (Sutabri, 2012). Sistem merupakan suatu kumpulan dari komponenkomponen yang membentuk satu kesatuan (Tyoso, 2016). Pembangunan sistem adalah sekumpulan aktivitas yang menggambarkan secara rinci bagaimana sistem akan berjalan. Hal itu bertujuan untuk menghasilkan produk perangkat lunak yang sesuai dengan kebutuhan user (Satzinger, J. W., Jackson, R. B., Burd, n.d.).

Diharapkan dengan adanya suatu sistem informasi dapat menangani permasalahan yang ada di perusahaan tersebut. Sistem adalah setiap sesuatu terdiri dari obyek-obyek, atau unsur-unsur, atau komponen-komponen yang bertata kaitan dan bertata hubungan satu sama lain, sedemikian rupa sehingga unsur-unsur tersebut merupakan satu kesatuan pemrosesan atau pengolahan yang tertentu. (Prasojo, 2011)
Aplikasi ini dapat memudahkan pekerjaan Admin dalam melaksanakan pembuatan laporan dan dapat memudahkan perusahaan dalam pendataan data peminjaman dan pengembalian mobil di Pusfatja LAPAN.

\section{METODE PENELITIAN}

Peneliti menggunakan metode Research and Development dalam penyelesaian penelitian ini. (Sugiyono, 2016). Dalam pelaksanaan R\&D, ada beberapa metode yang digunakan yaitu metode deskriptif, evaluatif dan eksperimental. Metode penelitian deskriptif digunakan dalam penelitian awal untuk menghimpun data tentang kondisi yang ada yaitu penulis membutuhkan data-data yang dapat menunjang tercipta nya suatu sistem informasi peminjaman dan pengembalian mobil seperti data mobil, data karyawan, data petugas, data peminjaman mobil dan data pengembalian mobil terdahulu yang masih tersimpan secara manual didalam buku besar. Metode evaluatif digunakan untuk mengevaluasi proses ujicoba pengembangan suatu produk, dalam proses ini penulis melakukan ujicoba terhadap suatu sistem yang telah dirancang agar tidak ada terjadi kesalahan dalam proses penginputan data serta pelaporan bulanan kepada pimpinan. Dan metode eksperimen digunakan untuk menguji keampuhan dari produk yang dihasilkan, dalam proses yang terakhir ini perlu dilakukan pengujian akhir yang diharapkan bahwa sistem yang dirancang oleh penulis dapat berjalan dengan baik dan sesuai dengan kebutuhan dan terfokus pada proses peminjaman dan pengembalian mobil PUSFATJA LAPAN (Putra, 2011).

\section{HASIL DAN PEMBAHASAN Analisa Permasalahan}

Dari hasil yang penulis lakukan maka penulis dapat menganalisis permasalahan yang ada pada PUSFATJA LAPAN, yaitu:

1. Sistem yang selama ini di pakai tidak efisien untuk pembuatan laporan dan kurang terjaga keamanannya. Jika admin ingin membuat laporan, maka arsip yang ada harus dikumpulkan dan dicatat satu persatu, tentu saja hal ini membuat bagian admin harus meluangkan waktu lebih banyak untuk pekerjaan ini.

2. Kurangnya sumber daya manusia yang memahami sistem komputerisasi menjadi 
suatu penyebab belum dibuatnya sistem aplikasi peminjaman dan pengembalian mobil di PUSFATJA LAPAN yang berbasis komputerisasi.

\section{Alternatif Penyelesaian Masalah}

Alternatif pemecahan masalah yang akan penulis lakukan untuk mempermudah proses kerja pada PUSFATJA LAPAN, yaitu:

1. Merancang sistem aplikasi yang lebih baik untuk dapat membantu kinerja bagian admin dalam mengelola setiap proses yang terjadi pada perusahaan serta membantu dalam mengolah data-data perusahaan.

2. Merancang sistem aplikasi manajemen data peminjaman dan pengembalian mobil dengan sistem terkomputerisasi. Jadi, setiap peminjaman dan pengembalian mobil yang terjadi, seperti proses peminjaman, pengembalian, dan data laporan akan disimpan ke dalam database. Kemudian laporan yang dibutuhkan akan ditampilkan secara otomatis tanpa harus menggunakan cara manual lagi.

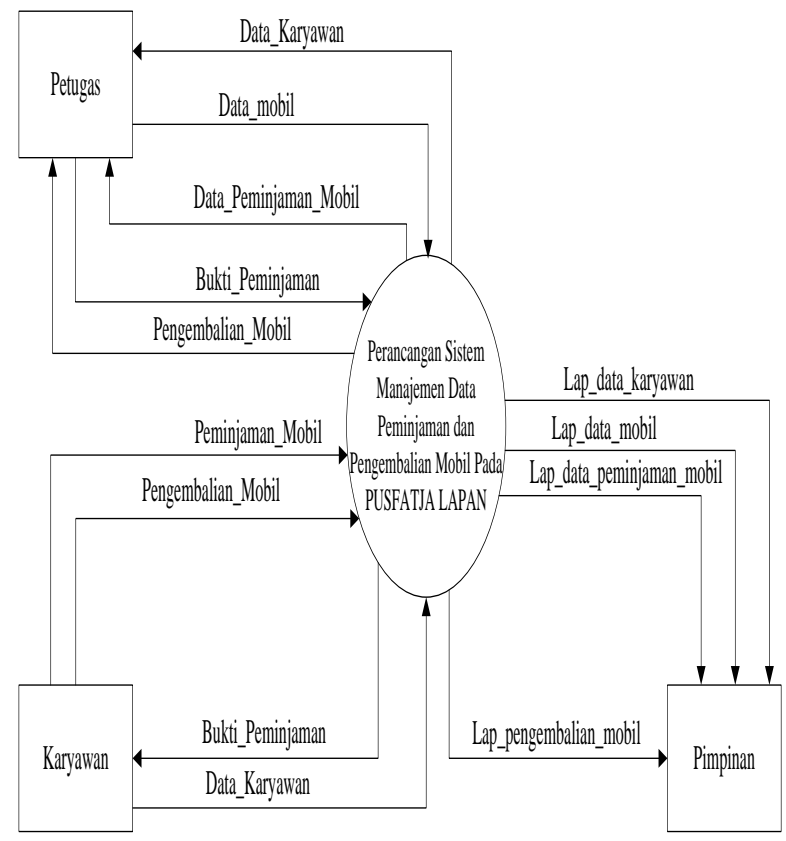

Gambar 1. Diagram Konteks

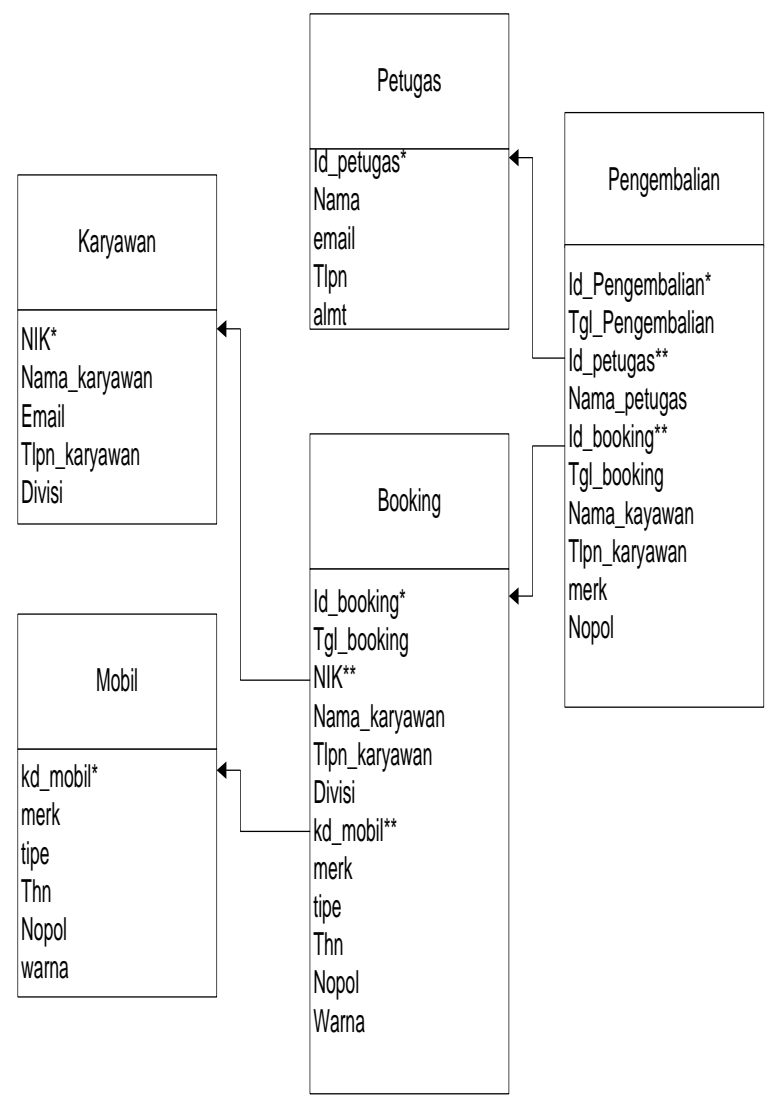

Gambar 2. Normalisasi

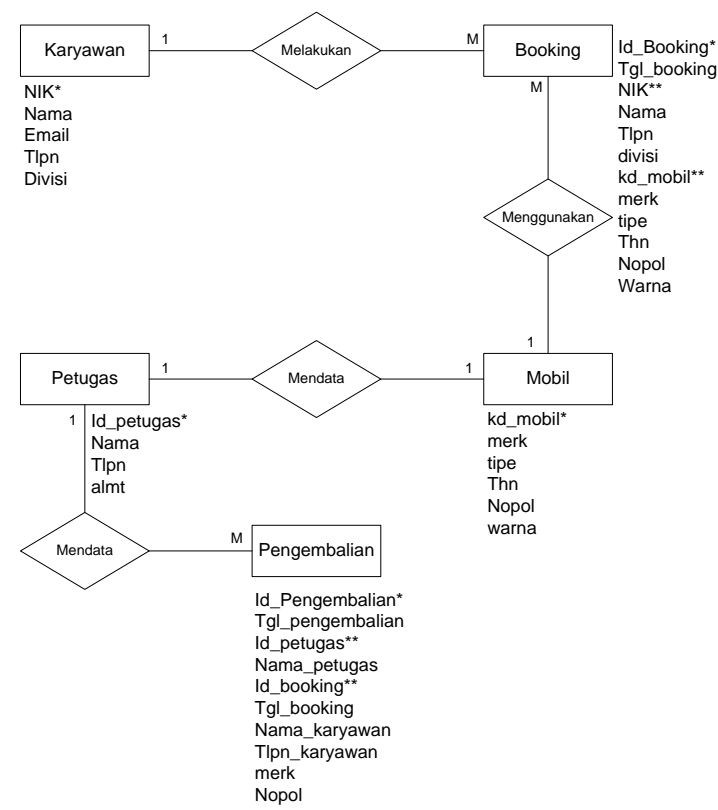

Gambar 3. ERD (Entity Relationship Diagram) 
Berikut adalah tampilan layar dan hasil pengujian pada software program yang telah di buat dengan bahasa pemrograman Java.

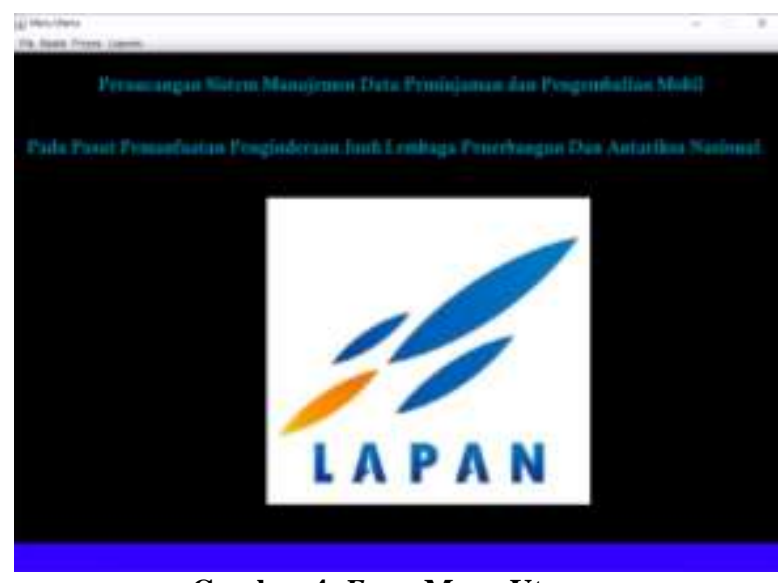

Gambar 4. Form Menu Utama

Layar di atas menampilkan tampilan Menu Utama pada Sistem Informasi Peminjaman dan Pengembalian Mobil Pada Pusfatja LAPAN. Pada layar utama tersedia menu bar yang terdiri dari master data yang digunakan untuk memasukkan data yang berkaitan dengan data karyawan, data petugas, data mobil, data peminjaman mobil, data pengembalian mobil dan laporan-laporan.

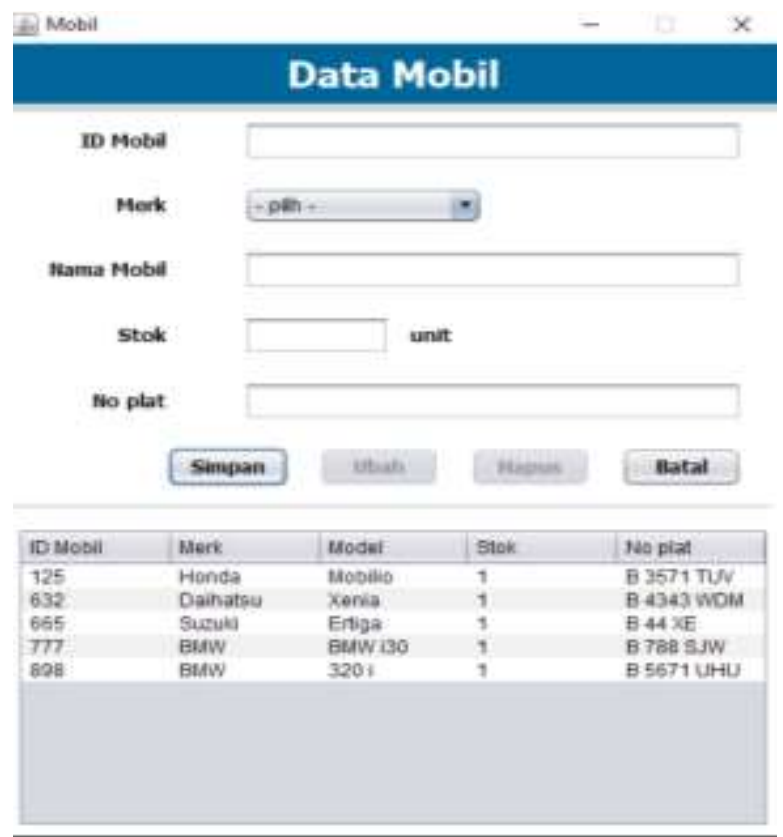

Gambar 5. Form Data Mobil

Layar di atas menampilkan tampilan form data mobil. Pada layar form data mobil untuk meng- input data mobil yang terdiri dari ID Mobil, Merk Mobil, Model, Stok dan No Plat Mobil.

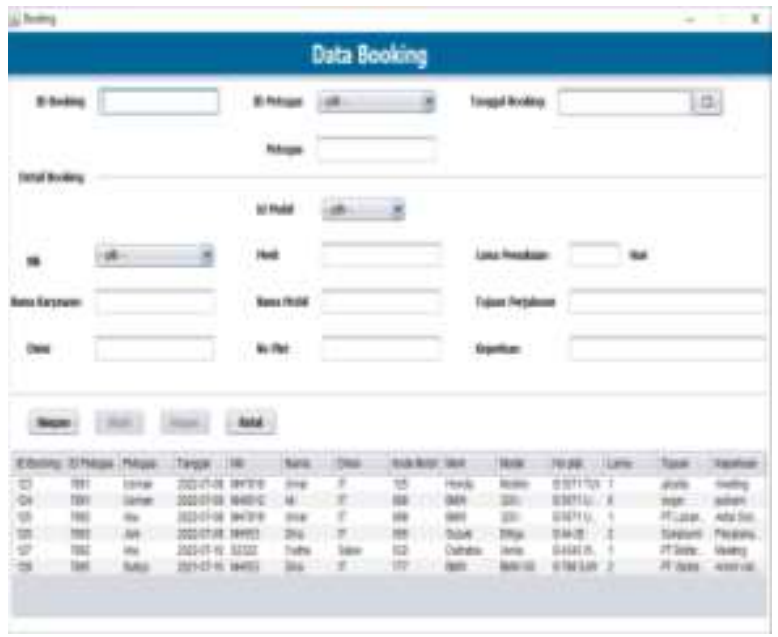

Gambar 6. Form Data Booking Mobil

Layar di atas menampilkan tampilan form data booking mobil. Pada layar form data booking mobil untuk meng-input data booking mobil yang terdiri dari ID Booking, ID Petugas, Nama Petugas, Tgl Booking, NI, Nama Karyawan, Divisi, ID Mobil, Merk, Nama Mobil, No Plat, Lama Pemakaian, Tujuan Perjalanan dan Keperluan.

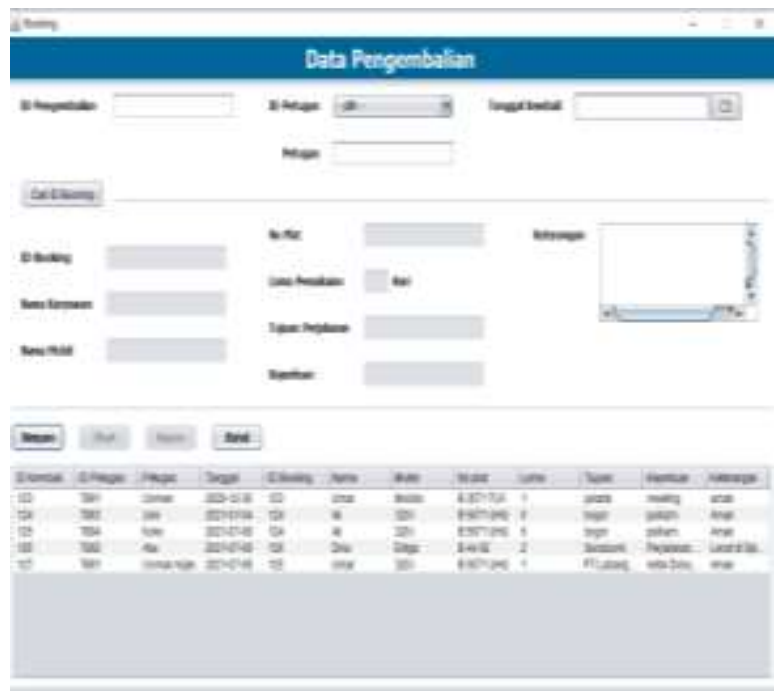

Gambar 7. Data Form Data Pengembalian Mobil

Layar di atas menampilkan tampilan form data pengembalian mobil. Pada layar form data pengembalian mobil untuk meng-input data pengembalian mobil yang terdiri dari ID Pengembalian, ID Petugas, Nama Petugas, Tgl Kembali, ID Booking, Nama Karyawan, Nama 
Mobil, No Plat, Lama Pemakaian, Tujuan Perjalanan, Keperluan dan Keterangan.

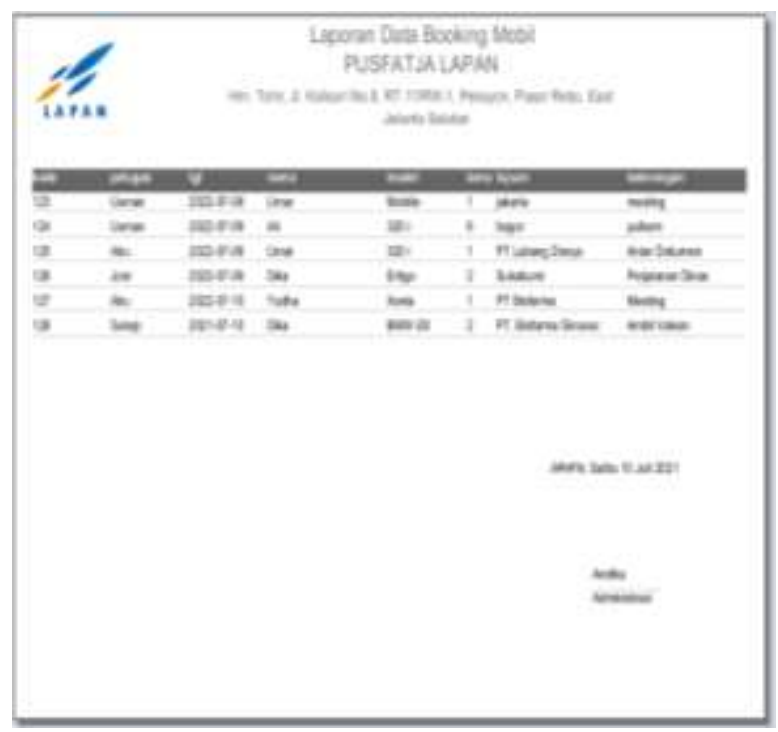

Gambar 8. Laporan Data Booking Mobil

Layar di atas menampilkan tampilan form laporan data booking mobil. Pada layar form data absensi digunakan untuk mengecek laporan data booking mobil terdiri Kode Booking, Nama Petugas, Tgl, Nama Petugas, Model, Lama Peminjaman, Tujuan dan Keterangan.

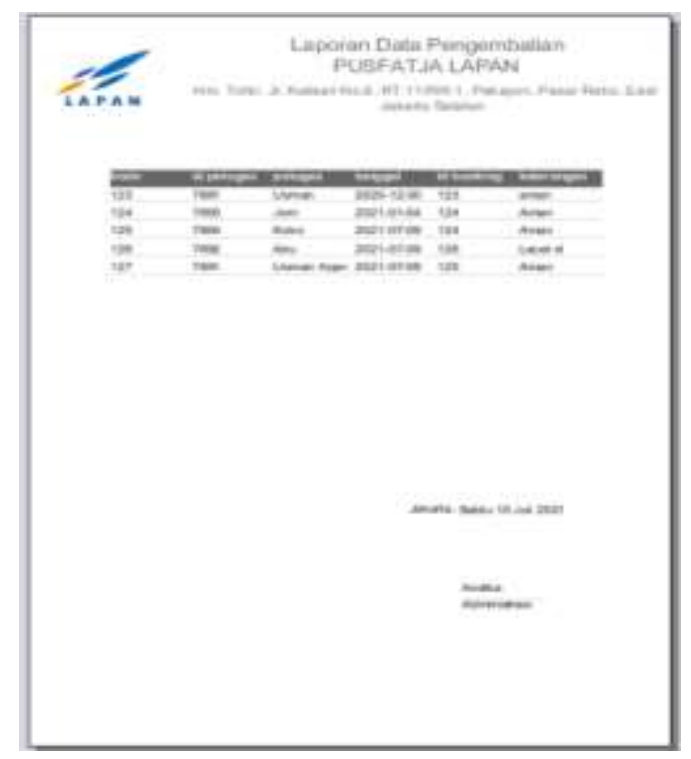

Gambar 9. Laporan Data Pengembalian Mobil

Layar di atas menampilkan tampilan form laporan data pengembalian mobil. Pada layar form data pengembalian mobil digunakan untuk mengecek laporan data pengembalian mobil terdiri Kode
Pengembalian, ID Petugas, Nama Petugas, Tgl, ID Booking dan Keterangan.

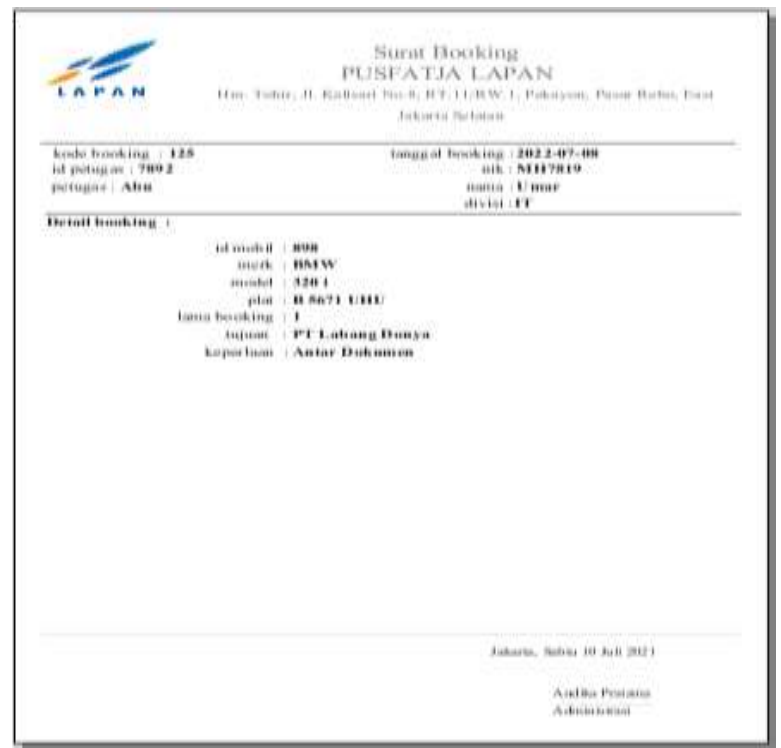

Gambar 10. Surat Booking Mobil

Layar di atas menampilkan tampilan surat booking mobil. Pada layar surat booking mobil terdiri dari Kode Booking, Tgl Booking, ID Petugas, Nama Petugas, NIK, Nama Karyawan, Divisi, ID Mobil, Merk, Mobil, No Plat, Lama Booking, Tujuan dan Keperluan.

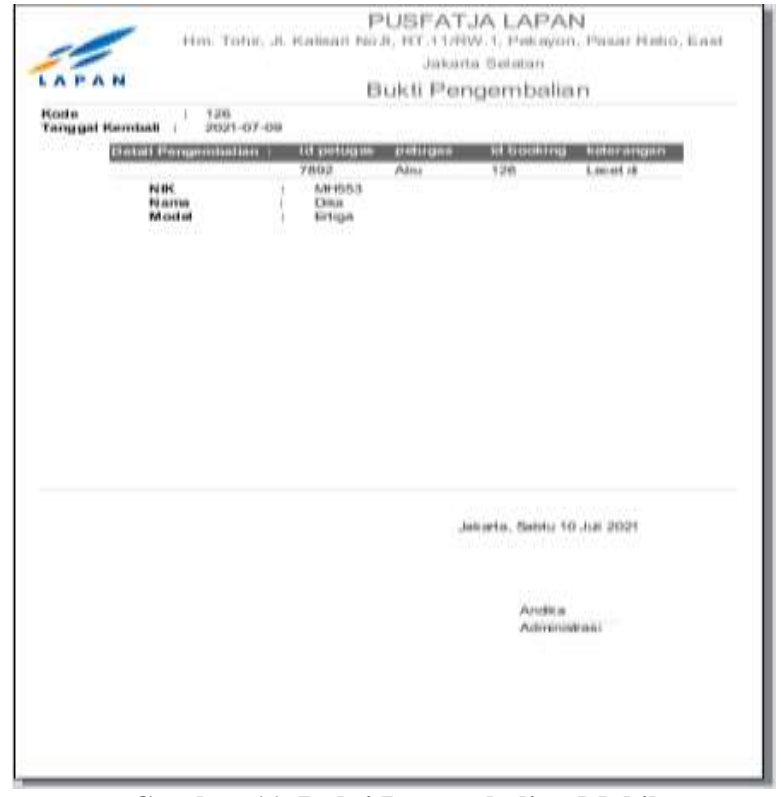

Gambar 11. Bukti Pengembalian Mobil

Layar di atas menampilkan tampilan bukti pengembalian mobil. Pada layar bukti pengembalian mobil terdiri dari Kode 
Pengembalian, Tgl Kembali, ID Petugas, Nama Petugas, ID Booking, NIK, Nama Karyawan, Model dan Keterangan.

\section{SIMPULAN DAN SARAN}

Aplikasi sistem peminjaman dan pengembalian mobil pada PUSFATJA LAPAN akan diperoleh informasi yang efektif dan efisien, yaitu membantu memperbaiki kesalahan dalam penulisan data, dan mempermudah dalam pembuatan laporan kepada pimpinan. Mengetahui sistem informasi peminjaman dan pengembalian mobil yang berjalan saat ini di PUSFATJA LAPAN sehingga dapat diketahui permasalahan yang ada di sistem informasi tersebut.

Serta sarannya adalah tindakan pengamanan perlu dilakukan karena komputer adalah alat yang sangat peka, maka keberadaannya harus dijaga dengan baik dan terawat. Oleh sebab itu resiko kehilangan data dan rusaknya data harus diantisipasi dengan cara mem-backup data secara berkala. Perlu adanya pengawasan terhadap penerapan sistem yang diusulkan sehingga bila terdapat kelemahan bisa segera diperbaiki.

\section{DAFTAR PUSTAKA}

Khasbi, I., Nugraha, F., \& Muzid, S. (2016). Sistem Informasi Peminjaman Ruang Dan Barang Di Universitas Muria Kudus Berbasis Web Menggunakan Fitur Sms Notification. Simetris : Jurnal Teknik Mesin, Elektro Dan Ilmu Komputer, 7(2), 513. https://doi.org/10.24176/simet.v7i2.762

Prasojo, M. (2011). Pengantar Sistem Informasi Manajemen . bandung: CV. Remadja Karya.

Pratama, D., \& Sariana, N. (2019). Rancang Bangun Sistem Informasi Penyewaan Kendaraan Berbasis Web. Jurnal Sistem Informasi Dan Sains Teknologi.

Puspaningrum, A., \& Sudarmilah, E. (2020). Sistem Informasi Manajemen Peminjaman (Studi Kasus: Pengelolaan Aset Dan Tata Ruang Taman Budaya Jawa Tengah). Technologia: Jurnal Ilmiah, 11(1), 37. https://doi.org/10.31602/tji.v11i1.2699

Putra, N. (2011). Research and Development, Penelitian dan Pengembangan: Suatu Pengantar. Jakarta: PT Raja Grafindo Persada.

Ramadhani, D. P., Saputra, F. A., Syahfitri, I. C.,
\& Herlawati, H. (2019). Metode Waterfall Dalam Sistem Informasi Penyewaan Mobil Berbasis Desktop. PIKSEL : Penelitian Ilmu Komputer Sistem Embedded and Logic. https://doi.org/10.33558/piksel.v7i1.1664

Satzinger, J. W., Jackson, R. B., Burd, S. D. (n.d.). System Analysis and Design in A Changing World. USA: Cengage Learning.

Sugiyono. (2016). Metode Penelitian Kuantitatif, Kualitatif dan $R \& D$. Bandung: PT Alfabet.

Sutabri, T. (2012). Analisis Sistem Informasi. Yogyakarta: Andi.

Tyoso, J. S. P. (2016). Sistem Informasi Manajemen. Yogyakarta: DeePublish.

Wahyudi, J. (2019). Pembangunan Sistem Aplikasi Penyewaan Mobil Berbasis Android. Studi Kasus: Cv. Amanah Kalimantan Rent. Jurnal JIEOM. 